\title{
The Review on the Link between Food and Oil Markets in the View of Price Dynamics
}

\author{
Ding Chen1,2,3, Umar Muhammad Gummi ${ }^{14^{*}}$, Abdulhamid Sillah Umar5 \\ ${ }^{1}$ School of Economics and Management, Xi'an Shiyou University, Xi'an, China \\ ${ }^{2}$ Silk Road Studies Institute, Northwest University, Xi'an, China \\ ${ }^{3}$ Shaanxi Economics and Management Research Center for Oil and Gas Resources, Xi'an, China \\ ${ }^{4}$ Department of Economics, Sokoto State University, Sokoto, Nigeria \\ ${ }^{5}$ International Business School, Xi'an Jiaotong-Liverpool University, Suzhou, China \\ Email: dhending 1981@163.com, ${ }^{*}$ muhammadgummiu@gmail.com
}

How to cite this paper: Chen, D., Gummi, U.M. and Umar, A.S. (2019) The Review on the Link between Food and Oil Markets in the View of Price Dynamics. American Journal of Industrial and Business Management, 9, 1890-1900.

https://doi.org/10.4236/ajibm.2019.99122

Received: August 6, 2019

Accepted: September 16, 2019

Published: September 19, 2019

Copyright $\odot 2019$ by author(s) and Scientific Research Publishing Inc. This work is licensed under the Creative Commons Attribution International License (CC BY 4.0).

http://creativecommons.org/licenses/by/4.0/

(c) (i) Open Access

\begin{abstract}
The long established link between food and oil prices in the global market is still uncertain in cross-country, regional and domestic analyses. In this paper, we review theoretical and empirical submissions on the nexus between food and oil market. Qualitative content analysis was used to critically analyze concepts and theories based on the past empirical evidences. The analysis shows that there is hardly a consistent and generalized submission on the direction of the relationship between oil price and agricultural commodity prices, as against the popular notion of co-movement between food and oil prices among researchers. However, studies on cross country analysis are scarce and among them, very few are related to oil exporting countries, hence the need to revisit the unending debate on the relationship between the two important markets based on economic structure (oil exporting/importing economy), capacity of an economy (high/low income economy) and the causes and nature of crisis in the markets.
\end{abstract}

\section{Keywords}

Oil Price, Food Price, Price Dynamics, Transmission Mechanisms, Oil Exporting Economies

\section{Introduction}

The global oil market was hit hard by yet another price shock, from an average of $\$ 100$ per barrel between the years 2012 and 2013 to $\$ 38$ per barrel in the third quarter of 2014 and continued to decline until the end of 2015, reaching a new record low of \$28 per barrel in January 2016 (OPEC, 2016) [1]. The fluctuations 
in oil experience during this period tend to have an effect on the global food prices given its role as input in the production process. Numerous factors according to Aleksandrova (2016) [2] contributed to the fall in oil prices, which was the biggest since the 1980s. The global market situation of sharp decline occurred as a consequence of the downward trend of global oil demand, European Union (EU) debt crisis and the slow recovery of the EU economy, appreciation of the US dollar and oil price reaction to a variety of geopolitical and economic phenomena. Incidences of high prices are not new in agricultural markets which are strongly linked to and influenced by the oil market. However, what distinguishes the current state of agricultural markets is the hike in prices of not only a selected few crops but nearly all major food and feed commodities (Dillion and Barret, 2015) [3], see Figure 1.

Food and oil markets have been a destabilizing element for the global economy because of their potential growth, inflationary and distributional effects. In terms of their immediate impact on income distribution, inflation and poverty, high food prices are of greater and more immediate concern than high oil prices (Ibrahim, 2015) [4]. The accompanying uncertainty, distortions and erosion of purchasing power in many countries call for concerted effort both at global and national levels to relieve people from the menace (FAO, 2016) [5]. According to Chen et al. (2010) [6], oil price fluctuation affects individual households and their basic needs indirectly through food inflation. In 2008 when the oil price fell drastically from $\$ 97$ to $\$ 39$, food price also follows the same trend (correspondingly decreased) and when the price of oil went up in 2009, food price steadily began to rise (Wambugu and Nganga, 2017) [7]. To be more precise, oil price fluctuation co-moves with inflation in general and food price in particular.

Debate on the statistical link between oil price and food price strengthened in 2006 (Aleksandrova, 2016) [2], with several studies concluded that higher and more unstable food prices will substantially hurt the poor because food is typically a large share of expenditure for the poor (Kargbo, 2005 [8]; Algalith, 2010 [9]; Du et al. 2011 [10]; Kalkuhlet al. 2016 [11] and Kimberly, 2017 [12]). Other

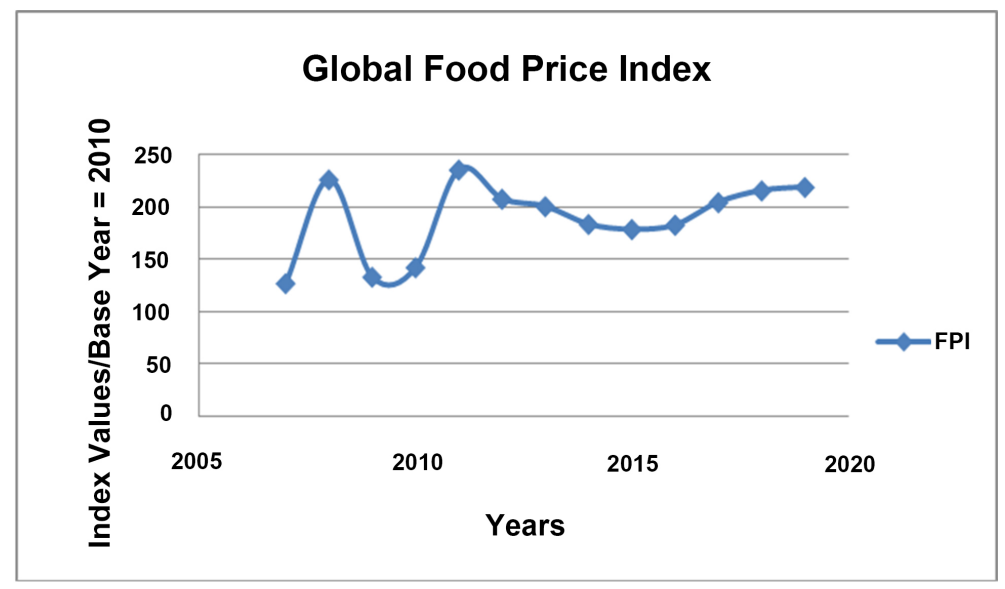

Figure 1. Fluctuations in food price. Source: FOA of the United Nations. 
studies focus on the price volatility in individual food items as affected by volatile oil price at international level (global market), the findings of these studies were not consistent even for individual commodities and the transmission mechanisms varied in relation to time (Gilbert and Morgan, 2010 [13]; Nazlioglu and Soytas, 2012 [14]; Minot, 2014 [15]; Tadesse et al. 2016 [16]; Olayungbu and Hassan, 2016 [17]; Wong and Shamsudin, 2017 [18]). The rising food price in recent years raised the question on whether oil price (market) has any explanatory power on the recent upward trend in agricultural food price (Nazlioglu et al. 2013 [19]). The food-energy nexus has become a controversial issue, with many researchers believing that oil price fluctuation is the main factor behind the historic shock in the agricultural market (Serra et al. 2011 [20]; Du et al. 2011 [10]; Pieters and Swinnen; Kalkuhl et al. 2016 [21]), yet others indicate that there is no direct linkage between oil price and agricultural commodity price, as investigated by Jebabli et al. (2014) [22]; Alom et al. (2013) [23]; Kristoufek et al. (2012) [24]; Sasmal (2015) [25]; Zhang et al. (2010) [26].

Based on the forgoing, the rationale behind this paper is to review empirical evidences and theoretical foundations on food and oil market nexus, and uncover the hidden issues that are significant in explaining the relationship based on the current dynamics in oil and food markets especially for oil exporting countries. However, the objective of the paper is to survey and evaluate existing theoretical and empirical submissions that examined the link between oil and food prices, and identify the uncovered issues in literature based on the price dynamics in the two markets in recent years. Furthermore, the paper rely on published empirical and theoretical researchers sourced from reputable journals in the study area, and based on their methodology, scope and findings, the current study identify its uniqueness and need for further researches. Implicitly, the study is limited by its inability to employ quantitative and econometric analysis to support its arguments, nevertheless, with the current submission, the paper serves as a beacon light for further researchers especially on price dynamics in the two market with emphasis on crisis periods.

Consequently, the paper is organized into four sections including this introduction. Section two the framework on the interactions between food and oil market; reviews some concepts, theories and empirical literature. Section three evaluates the review and discuses on the new approach motivated by the recent shocks in the oil market. Section four presents the concluding remarks.

\section{Interactions between Food and Oil Markets: The Framework}

Recent studies have identified the causes of food price hikes as biofuel demand, speculation in commodity futures markets, and macroeconomic shocks. These variables represent both the demand and the supply side of the world food equation (Tadesse et al. 2016) [16]. In an attempt to distinguish how different factors affect price changes, three groups of potential causes have been singled out by 
Tadesse et al. (2016) [16]: exogenous shocks, also called "root" causes; "conditional" causes; and "internal" drivers. Root causes, such as extreme weather events, oil price shocks, production shocks, and demand shocks, are independent core factors affecting food price fluctuations. They are exogenous because the possibility of a causal relationship between the agricultural sector and root causes is minimal. Exogenous shocks are expected to generate food price spikes and volatility, and the magnitude of their impacts depends partly on the political and economic environment of a given country.

In other words, a second group of factors related to specific political and economic conditions labeled here as conditional drivers can dampen or exacerbate exogenous shocks. Some of these factors (such as a high concentration of production or low transparency in commodity markets) are time invariant and rather difficult to measure; they are therefore not considered in the empirical analysis in this chapter. The third group of causes consists of factors that are triggered by the same price dynamics, and these internal causes are endogenous shock amplifiers and include discretionary trade policies, speculative activities (driven by price expectations), and declines in world food stocks, see Figure 2.

\subsection{Theoretical Discourse}

\subsubsection{Theory of Demand and Supply}

Both demand and supply forces drive the behavior of food prices in the global, regional and domestic markets. Under competitive market conditions, price of commodities is determined by the interaction of individual producers and individual consumers in the market. To Kargbo (2005) [8], this relationship between food market participants can be represented using the following expressions;

$$
\begin{array}{lc}
\text { Let Demand } & \left(Q_{d t}\right)=f\left(P_{f t}, Y_{t}, Z_{t}\right) \\
\text { Supply } & \left(Q_{s t}\right)=f\left(P_{f t}, E X C_{t}, O P_{t}\right) \\
\text { At Equilibrium } & Q_{d t}=Q_{s t}=P_{f t}
\end{array}
$$

where $P_{f t}$ is the real price of food, that is nominal food price deflated by GDP deflator. $Y_{t}$ measured as real per capita GDP is real per capita income and $Z_{t}$ represents other variables that influence food demand. The subscripts: $t=1,2, \cdots, n$ represents time periods, and $s$ is the lag period. $E X C_{t}$ is real exchange rate measured in US Dollar and $O P_{t}$ is the price of crude oil in the international market. Demand factors in the food market are presented in Equation (1), supply factors in Equation (2) while Equation (3) depicts the equilibrium condition between demand and supply factors that establish a price.

However, the equilibrium equation can be re-written as

$$
P_{t}=f\left(Y_{t}, O P_{t}, E X C_{t}, Z_{t}\right)
$$

Equation (4) accommodates the effect of demand and supply forces on prices in the food market as well as the transmission mechanisms that influence directly or indirectly the movements in food price. 


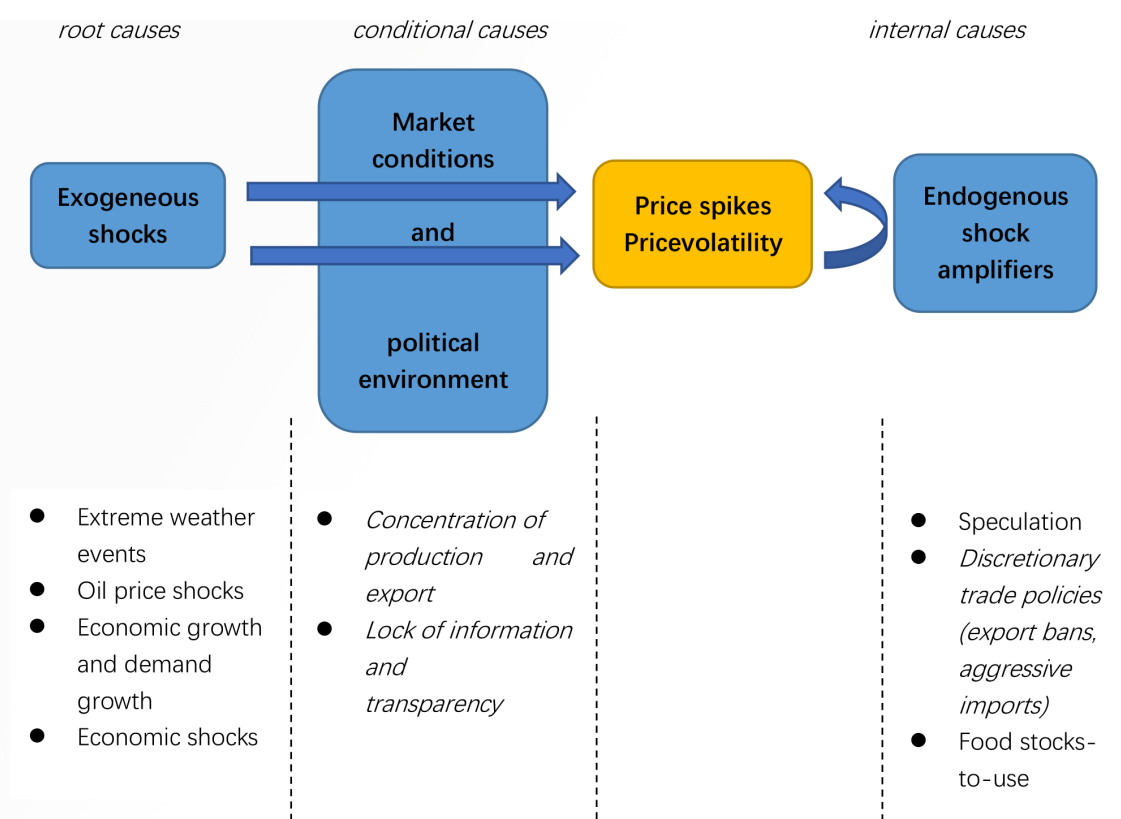

Figure 2. Stylized framework of the causes of global food price fluctuations. Source: Adopted from Tadasse et al. (2016) [16].

\subsubsection{Oswald's Transmission Channels}

Even though there is no consensus in literature on how oil prices influence food prices and to which extent? Three potential transmission channels which can establish a causal relationship from oil prices to food prices have been identified by Oswald (2016) [27] in his seminal work titled "The effect of oil price(s) on food price(s): A global perspective". From a general view point, the Food Prices Watch (FPW) in 2015 states that energy prices heavily influence fertilizer prices and other production inputs of agriculture. It further asserts that the biofuel sector created a link between oil prices and food prices. In essence, oil price influences food prices via transport costs and fertilizer costs.

The three transmission channels affect the price of food stuffs as observed by Oswald (2016) [27] while considering 17 cities in the East African region are transportation, the biofuel sector and other production costs (with an emphasis on fertilizers). Figure 3 depicts the framework that shows how oil price fluctuations influence food prices via the three channels. Distance exerts impact on the transport costs, for bringing food from the city to the harbor, this influences the food price. Oil serves as fuel for the transportation. The farther one wants to transport food items, the higher oil price has to be paid and thus reflected in the price of food, see Figure 3.

The transmission mechanism of oil price via biofuel demand is indirect and complex. It is concerned with the relationship for commodities which can be either used for biofuel production or for food processing (such as maize, corn etc.). It is obvious from Figure 4 that the oil price exists in a positively proportional relationship with the biofuel demand. If oil gets more expensive, more people will resort to biofuel instead. If oil prices fall, less of biofuel will be demanded by people. The biofuel demand therefore influences biofuel price. If 


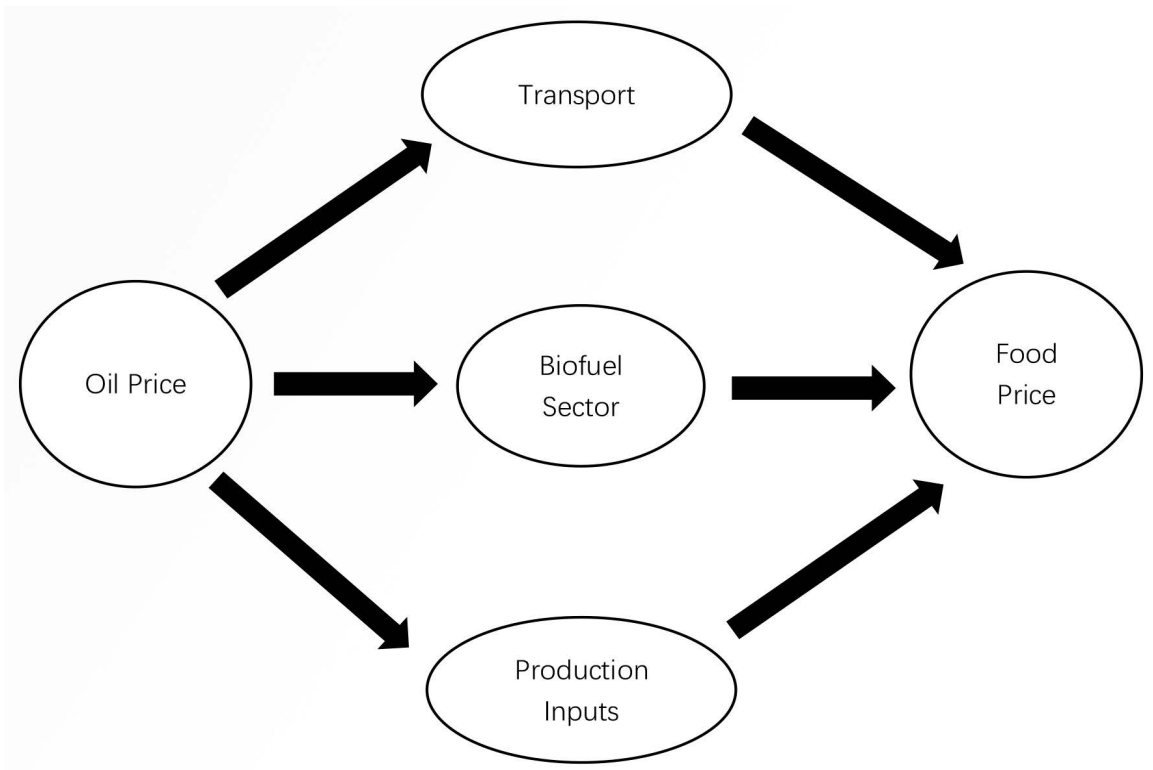

Figure 3. Transmission channels from oil price to food price. Source: Adopted from Oswald

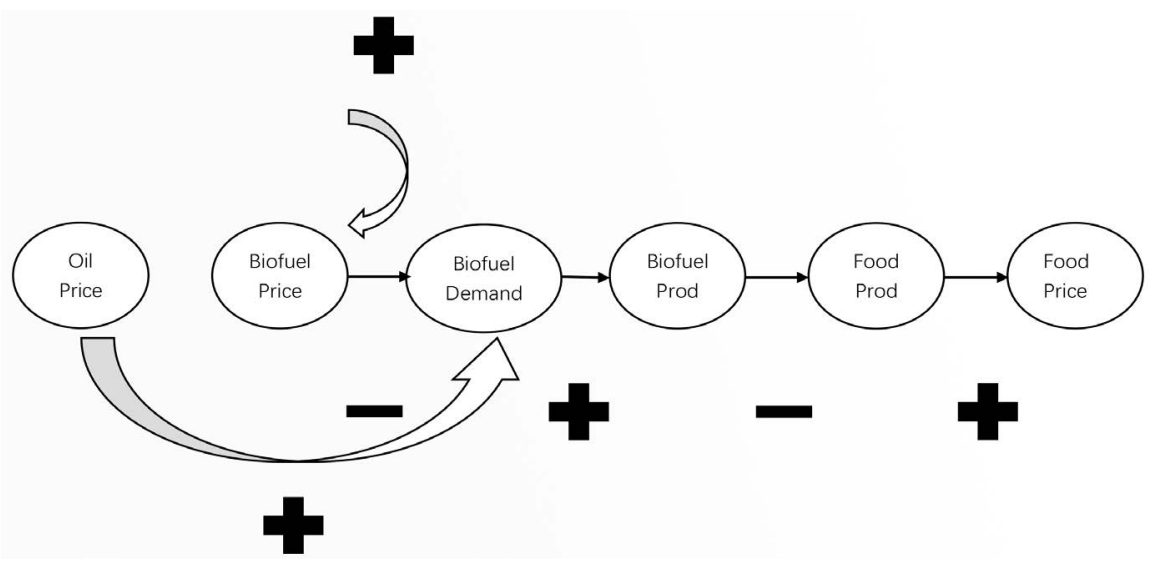

Figure 4. Transmission mechanisms of distance and biofuel on food prices. Source: Adopted from Oswald (2016) [27].

there is high demand in relation to the supply, the price will go up as a convention and vice versa. Reciprocally, the demand determines the volume of biofuel production and this volume of biofuel production determines how much grains, let say maize is used for biofuel production instead off or food production. If less amount of maize goes into food production, less of it will be available for food purposes and its price increases due to shortage in the market. But in Figure 4 reduction in food price is reflected by Oswald despite decrease in food production. This assertion is refuted by the study considering theoretical foundation on which it is formulated and simple economic analysis of demand and supply, see Figure 4.

\subsubsection{The Dutch Disease}

Dutch disease refers to an apparent causal relationship between the increasing 
economic development of a particular sector (for e.g. natural resources) and a decline in other sectors (like the manufacturing, service or agriculture sectors). The expectation is that, as revenues increase in the natural resource sector (or inflows of foreign exchange), the country's currency becomes stronger (appreciates) compared to other countries' currencies. But the implication is that, the country's other exports will become more expensive for other countries, and imports becoming cheaper, making those sectors less competitive.

Corden and Neary (1982) [28] developed a framework describing Dutch disease using three-sector economy, namely; resource sector (R), tradable sector $(\mathrm{T})$ and manufacturing sector (M). In the late 1950s, Netherland witnessed significant appreciation in their currency (Guilder), which followed the natural gas export boom, caused inflation which in turn leads to reduction in competitiveness and profitability of the manufacturing and service sectors. Subsequently, aggregate export crashed down relative to GDP. The theory is guided by the four assumptions as put forth by Corden and Neary (1982) [28] which are perfect mobility of labor among all the three sectors, all commodities are for final consumption, trade always balance (output equals spending) and commodity and factor prices are free from distortions.

Based on these assumptions, they identified two major effects of the resource boom in an economy. One is resource movement effect, saying the natural resource boom increases demand for labor, which causes production to shift toward the booming sector, away from the lagging sectors. This shift in labor from the lagging sector to the booming sector is called direct-deindustrialization. The other factor is spending effect, saying this occurs as a result of the extra revenue maximized from the resource boom. It increases demand for labor in the non-tradable sector (services), at the expense of the lagging sector. This shift from the lagging sector to the non-tradable sector is called indirect-deindustrialization. The increased demand for non-traded goods increases their price. However, prices in the traded good sector are set internationally, so they cannot change. This amounts to an increase in the real exchange rate.

From this view, the above theories present the nature and relationship between oil and food markets and all of them can be utilized to as working theories in explaining the nexus between oil price shocks and food price in oil producing countries. Oil price shocks exert variations in the demand and supply of food especially in oil exporting countries, and price dynamics are often explained in terms of demand and supply forces (market mechanisms). The transmission mechanisms as put forth by Oswald (2016) [27] explain the nature of food production as oil price changes overtime. This significantly impact on the cost of transportation, cost of fertilizer and biofuel production as alternative for oil. The classical economic model of the Dutch disease by Corden and Neary (1982) [28] presents a situation where most of the oil producing/exporting nations neglect their real sector (agricultural sector) and concentrate on the oil sector to maximize revenue. This crowd out the real sector and undermine its capacity to produce necessities (basic goods) to match the demands of their people. As such, 
they resort to import and pay higher prices which they feel insignificant given the amount of revenues they generated from the sale of oil in the international market especially when its price rises.

However, oil and food prices nexus has been established but the debate on the extent of the relationship and impact (positive or negative) of oil price on food price is yet to be ascertained as a consensus in empirical literatures. With positive impact of oil price on food price recorded in most of the theories, there exist some exceptions, considering the dynamic nature of the oil market characterized by short term and long term fluctuations. For oil importing countries, oil price is expected to exert positive impact on the price of food stuffs via transportation and input cost. In addition, oil exporting countries earn revenues for exporting crude oil through the foreign exchange market which adds to the national output hence economic growth when oil price increases in the international market. Furthermore, if oil price decreases in the international market, it will be a disincentive for oil exporting countries as it serves as the major source of revenue to their government in financing development. Less revenue means less income and growth which leads to lower demand for goods and services.

Nevertheless, the demand shocks tend to be high when oil price is higher in the international market for oil based economies but when there is downward price spikes in the market the expectations would be reduction in the composition of food stuffs purchased by the people due to demand shocks and food price is also expected to decrease in the said economies. Unfortunately, recent data revealed that food prices are on the increase despite drastic reduction of oil price in the global market due to shocks from the fourth quarter of Year 2014 to the third quarter of Year 2017. The data for oil based economies on food price refuted the existing views that crude oil price exerts positive impact on food prices.

\section{Evaluation and Further Research Needs}

After careful review of relevant and related literature in the study area, it was found that a significant number of researchers devoted their efforts to empirically examine the behavior of price series in food and oil markets with convergent and divergent views. The debate on the link between oil price and food price is far from over given the dynamic nature of oil and agricultural commodity markets. Few studies were conducted on cross country analysis (panel studies) and very few were conducted on oil exporting countries as in Alghalith (2010) [9]; Kargbo (2005) [8]; Olayungbo and Hassan (2016) [17]. And even for oil exporting countries, there are variations from the empirical findings. This signals to the fact that based on reliable data, economic structure, capacity of the economy in question and the nature and cause of the crisis in either market play a significant role in determining the relationship between food and oil prices. Furthermore, there is the need to differentiate between positive changes from negative changes in oil price (oil price asymmetry), and its impact on food price. From this view, one can infer and isolate the impact of oil price on food price based on downward or upward trends. Also, the notion of generalizing on the 
relationship in oil importing and oil exporting countries can be ascertained over time horizons and nature of trends in oil and food markets.

\section{Conclusion}

The paper reviews theoretical and empirical discourse on the relationship between food and oil markets. After critical survey of the sourced information, it was found that few studies were conducted on cross country analysis and even among them, very few were conducted on oil exporting countries which are limited in terms of their approach and methods. Food and oil price dynamics behaves differently when dealing with different economic structures, different economic capacity and when crisis in the two markets differs in term of their nature and period. Therefore, this warrant further researches that will comprehensively address the key issues identified in this paper, hence the need to ascertain the magnitude of the effects oil price asymmetry on food price during and after crisis in the oil market.

\section{Acknowledgements}

The first author would like to acknowledge the financial support from the Scientific Research Program Funded by Shaanxi Provincial Education Department (Program No. 19JZ051) and the Scientific Research Program Funded by Silk Road Study Institute of Northwest University (Item No. XDSR201701). Authors also acknowledge the support of the Petroleum Technology Development Fund.

\section{Conflicts of Interest}

The authors declare no conflicts of interest regarding the publication of this paper.

\section{References}

[1] Organization of Petroleum Exporting Countries OPEC (2016) World Oil Outlook (WOO) Publication of the OPEC. http://www.opec.org/opec_web/en/publications/340.htm

[2] Aleksandrova, S. (2016) Impact of Oil Price on Oil Exporting Countries in the Caucasus and Central Asia. Economic Alternative, 4, 477-486. https://www.unwe.bg/uploads/Alternatives/S_A_2016_Issue4_en-5.pdf

[3] Dillon, B.M. and Barret, C.B. (2015) Global Oil Prices and Local Food Prices: Evidence from East Africa.

http://barrett.dyson.cornell.edu/files/papers/150131_DillonBarrett_GlobalOilLocalF ood.pdf

[4] Ibrahim, M.H. (2015) Oil and Food Prices in Malaysia: A Nonlinear ARDL Analysis. Agriculture Land Food Economics, 3, 28-35. https://doi.org/10.1186/s40100-014-0020-3

[5] Food and Agricultural Organization FAO (2016) FAO's Food Price and Output Watch Database, FAOSTAT. http://www.fao.org/statistics/databases/en

[6] Chen, S.T., Kua, H.I. and Chen, C.C. (2010) Modelling the Relationship between the Oil Price and Global Food Prices. Applied Energy, 87, 2517-2525. 
http://www.sciencedirect.com/science/article/pii/S0306-2619(10)00051-6 https://doi.org/10.1016/j.apenergy.2010.02.020

[7] Wambugu, C.K. and Ngang'a, J. (2017) Relationship between Oil Price, Exchange Rate and Maize Price in Kenya. International Journal of Finance, 1, 88-107. https://carijournals.org/journals/index.php/IJF/article/view/44/94

[8] Kargbo, J.M. (2005) Impact of Monetary and Macroeconomic Variables on Food Prices in West Africa. Agrekon, 44, 205-224.

https://doi.org/10.1080/03031853.2005.9523710 https://www.tandfonline.com/doi/abs/10.1080/03031853.2005.9523710

[9] Alghalith, M. (2010) The Interaction between Food Prices and Oil Prices. Energy Economics, 32, 1520-1522. https://doi.org/10.1016/j.eneco.2010.08.012

[10] Du, X., Yu, C.L. and Hayes, D.J. (2011) Speculation and Volatility Spillover in the Crude Oil and Agricultural Commodity Markets: A Bayesian Analysis. Energy Economy, 33, 497-503. https://doi.org/10.1016/j.eneco.2010.12.015 http://www.sciencedirect.com/science/article/pii/S0140-9883(11)00017-X

[11] Kalkuhl, M., Braun, J. and Torero, M. (2016) Volatile and Extreme Food Prices, Food Security, and Policy: An Overview. In: Food Price Volatility and Its Implications for Food Security and Policy, Springer International Publishing, Berlin, 3-31. https://mpra.ub.uni-muenchen.de/72164/1/MPRA_paper_72164.pdf https://doi.org/10.1007/978-3-319-28201-5_1

[12] Kimberly, A. (2017) What Is Crude Oil? Prices, Trends and Impact on the Economy.

https://www.thebalance.com/crude-oil-prices-trends-and-impact-on-the-economyand-you-3305738

[13] Gilbert, C.L. and Morgan, C.W. (2010) Food Price Volatility. Philosophical Transactions of the Royal Society B: Biological Sciences, 365, 3023-3034. https://doi.org/10.1098/rstb.2010.0139

[14] Nazlioglu, S. and Soytas, U. (2012) Oil Price, Agricultural Commodity Prices, and the Dollar: A Panel Cointegration and Causality Analysis. Energy Economics, 34, 1098-1104. https://doi.org/10.1016/j.eneco.2011.09.008

[15] Minot, N. (2014) Food Price Volatility in Sub-Saharan Africa: Has It Really Increased? Food Policy, 45, 45-56. https://doi.org/10.1016/j.foodpol.2013.12.008

[16] Tadasse, G., Algieri, B., Kalkuhl, M. and von Braun, J. (2016) Drivers and Triggers of International Food Price Spikes and Volatility. In: Food Price Volatility and Its Implications for Food Security and Policy, Springer International Publishing, Berlin, 59-82. https://mpra.ub.uni-muenchen.de/72164/1/MPRA_paper_72164.pdf https://doi.org/10.1007/978-3-319-28201-5_3

[17] Olayungbo, D. and Hassan, W. (2016) Effect of Oil Price on Food Price in Developing Oil Exporting Countries: A Panel Autoregressive Distributed Lag Analysis. OPEC Energy Review, 40, 397-411. https://doi.org/10.1111/opec.12090

[18] Wong, S.K. and Shamsudin, N.M. (2017) Impact of Crude Oil Price, Exchange Rate and Real GDP on Malaysia's Food Price Fluctuations: Symmetric or Asymmetric? International Journal of Economics and Management, 11, 259-273.

http://psasir.upm.edu.my/id/eprint/56379/1/\%2814\%29-Paper\%2014\%20Fnal-IJEM \%2011\%281\%29\%2C2017_Food\%20price\%20and\%20oil\%20price $\% 20 \% 281 \% 29 . p d f$

[19] Nazlioglu, S., Erdem, C. and Soytas, U. (2013) Volatility Spillover between Oil and Agricultural Commodity Markets. Energy Economics, 36, 658-665. https://doi.org/10.1016/j.eneco.2012.11.009

[20] Serra, T., Zilberman, D., Gil, J.M. and Goodwin, B.K. (2011) Nonlinearities in the 
U.S. Corn-Ethanol-Oil-Gasoline Price System. Agriculture Economics, 42, 35-45. https://ageconsearch.umn.edu/bitstream/6512/2/464896.pdf https://doi.org/10.1111/j.1574-0862.2010.00464.x

[21] Pieters, H. and Swinnen, J. (2016) Trading-off Volatility and Distortions? Food Policy during Price Spikes. Food Policy, 61, 27-39. https://doi.org/10.1016/j.foodpol.2016.01.004

[22] Jebabli, I., Arouri, M. and Teulon, F. (2014) On the Effects of World Stock Market and Oil Price Shocks on Food Prices: An Empirical Investigation Based on TVP-VAR Models with Stochastic Volatility. Energy Economics, 45, 66-98. https://doi.org/10.1016/j.eneco.2014.06.008

[23] Alom, F., Ward, B.D. and Hu, B. (2013) Macroeconomic Effects of World Oil and Food Price Shocks in Asia and Pacific Economies: Application of SVAR Models. OPEC Energy Review, 37, 327-372. https://doi.org/10.1111/opec.12015 https://onlinelibrary.wiley.com/doi/abs/10.1111/opec.12015

[24] Kristoufek, L., Janda, K. and Zilberman, D. (2012) Correlations between Biofuels and Related Commodities before and during the Good Crisis: A Taxonomy Perspective. University of California Center for Energy and Environmental Economics, Working Paper.

[25] Sasmal, J. (2015) Food Price Inflation in India: The Growing Economy with Sluggish Agriculture. Journal of Economics, Finance and Administrative Science, 20, 30-40. https://doi.org/10.1016/j.jefas.2015.01.005

[26] Zhang, Z., Lohr, L., Escalante, C. and Wetzstein, M. (2010) Food versus Fuel: What Do Prices Tell Us? Energy Policy, 38, 445-451.

https://doi.org/10.1016/j.enpol.2009.09.034

http://www.sciencedirect.com/science/article/pii/S0301-4215(09)00717-4

[27] Oswald, Y. (2016) The Effect of Oil Prices on Food Prices: A Global Perspective. Seminar Paper Presentation on Agriculture and Food Security, Teri University, New Delhi, 29 October 2016.

[28] Corden, W.M. and Neary, J.P. (1982) Small Open Economy. The Economic Journal, 92, 825-848. https://doi.org/10.2307/2232670 